CZASOPISMO INŻYNIERII LA¿OWEJ, ŚRODOWISKA I ARCHITEKTURY JOURNAL OF CIVIL ENGINEERING, ENVIRONMENT AND ARCHITECTURE

JCEEA, t. XXXIV, z. 64 (3/II/17), lipiec-wrzesień 2017, s. 455-466, DOI:10.7862/rb.2017.186

\author{
Grzegorz ZAMOYSKI ${ }^{1}$
}

\title{
IZAAK APPERMAN - ZAPOMNIANY RZESZOWSKI ARCHITEKT
}

\begin{abstract}
Izaak Apperman był najbardziej aktywnym żydowskim architektem, działającym w Rzeszowie pod koniec XIX wieku. Jego życiorys kryje wiele tajemnic - nie udało się odnaleźć żadnych dokumentów związanych z zamieszkaniem w tym mieście. Pracował w Wiedniu, ale wiele jego prac zostało zrealizowanych w Rzeszowie. Był projektantem części obiektów; ale także - prowadząc własne przedsiębiorstwo budowlane - wykonawcą projektów innych architektów. Pozostały po nim obiekty, które na trwale wpisały się w krajobraz miasta. Budynki te realizował na potrzeby miasta, miejscowej gminy żydowskiej, instytucji państwowych, stowarzyszeń i osób prywatnych. Wśród nich należy wymienić m.in. zachowane budynki rzeszowskiego Towarzystwa Gimnastycznego „Sokół” (ul. Bernardyńska), szpitala zakaźnego (ul. Naruszewicza), gmachu Izby Skarbowej (ul. Zamkowa), Kasy Oszczędności (obecna Galeria „Paniaga” przy ul. 3 Maja), strażnicy miejskiej (obecnie ul. Lisa-Kuli), prywatne budynki przy ulicach Trzeciego Maja, Dymnickiego czy Kopernika wreszcie projekt rzeźni w Ruskiej Wsi. Do prowadzonych badań wykorzystano zachowane w dobrym stanie archiwalia z rzeszowskiego Archiwum Państwowego, zgromadzone w zespole Akta miasta Rzeszowa. Dokumentację tę stanowią projekty budynków oraz korespondencja $\mathrm{z}$ inwestorami i władzami miasta, wydającymi zgodę na budowane obiekty oraz sprawującymi nadzór nad realizacją inwestycji.
\end{abstract}

Słowa kluczowe: historia architektury, Galicja, Rzeszów, architekci w Rzeszowie

Izaak Apperman - architekt i przedsiębiorca budowlany - jest postacią tajemniczą. W Rzeszowie pozostawił po sobie wiele budynków, które na trwałe wpisały się w obraz miasta. Pojawił się nagle na początku lat 90-tych XIX wieku i równie szybko zniknął w pierwszych latach kolejnej dekady. Pozostały po nim budynki - podpisywał ich projekty własnym nazwiskiem, bądź też jako przedsiębiorca budowlany wybudował wraz ze wspólnikami.

Niewiele o nim wiadomo. Kwerenda, przeprowadzona w rzeszowskim Archiwum Państwowym w zespole Akta miasta Rzeszowa, nie przyniosła spodziewanych rezultatów. Nie udało się bowiem odnaleźć żadnych wzmianek na jego

\footnotetext{
${ }^{1}$ Autor do korespondencji/corresponding author Grzegorz Zamoyski, Politechnika Rzeszowska, Katedra Nauk Humanistycznych, al. Powstańców Warszawy 12, 35-959 Rzeszów; tel.: 17865 1529; e-mail: grzam@prz.edu.pl
} 
temat w zachowanych spisach ludności miasta z lat 1890 i 1900; brak jego nazwiska także w księgach metrykalnych miejscowego izraelickiego urzędu metrykalnego. Nie wiadomo, kiedy do Rzeszowa przybył, gdzie zamieszkał i jaki był jego stan cywilny. Nie wiemy też skąd pochodził - ale dobra znajomość języka polskiego, poświadczona liczną zachowaną korespondencją z władzami Rzeszowa wskazuje, że prawdopodobnie pochodził z Galicji ${ }^{2}$.

Wiadomo jednak, że do Rzeszowa przyjechał z Wiednia. Zachował się bowiem dokument notarialny, sporządzony w Wiedniu w roku 1890 przez notariusza Emanuela Schiffmanna, który wskazywał miejsce zamieszkania Izaaka Appermana w Wiedniu przy Klanggasse $1^{3}$. To niewielka uliczka w 2 . Bezirku tego miasta, przy wejściu do parku Augarten. Budynek ten nie zachował się - został zniszczony w wyniku działań wojennych w 1945 r. W jego miejscu znajduje się obecnie niewielki skwer. $Z$ kolei w projekcie budynku Sperlingów przy ulicy Trzeciego Maja z 1904 r. Apperman podpisał się jak ,Stadt-Baumeister, Wien Dornbacherstrasse 103"'4. Lata 1890-1904 to czas jego działalności w Rzeszowie.

Niewielką wzmiankę poświęconą działalności I. Appermana zamieściła Barbara Tondos w swym opracowaniu, poświęconym architekturze galicyjskiego Rzeszowa $^{5}$. Ona także była autorką jego biogramu w kolejnych wydaniach „Encyklopedii Rzeszowa" ${ }^{\circ}$. Barbara Tondos w swoich pracach pominęla jednak wiele projektów, których autorstwo i wykonawstwo należy przypisać Appermanowi. Ponadto części z nich nie zdołała zidentyfikować, choć było to możliwe, znając liczbę konskrypcyjną budynku, która jeszcze na początku XX wieku pełniła rolę adresu. [1 3$]$

Przykładem może być pochodzący z 1897 roku projekt dwupiętrowego budynku Leisora Koretza przy ówczesnej ulicy Nowej. W roku 1899 nazwę tej ulicy zmieniono na ulicę Kopernika ${ }^{7}$. Zachowany projekt wskazuje, że chodzi o budynek położony na rogu dzisiejszych ulic Kopernika i Okrzei. Projekt zachował się jedynie w postaci rzutów poszczególnych kondygnacji; brak projektów fasad od strony obu ulic. Projekt ten został zatwierdzony do budowy we wrześniu 1897 r. przez ówczesnego burmistrza Stanisława Jabłońskiego ${ }^{8}$.

\footnotetext{
${ }^{2}$ Według wykazu żydowskich nazwisk z Galicji, nazwisko Apperman występuje w aktach metrykalnych w Łańcucie, Przemyślu, Rawie, Sokalu, Kamionce Strumiłowej, Lwowie, Samborze, Drohobyczu, Stryju, Stanisławowie, Trembowli, Tarnopolu i Brodach, zob. A. Beider, A dictionary of jewish surnames from Galicia, Bergenfield 2004, s. 96.

${ }^{3}$ Archiwum Państwowe w Rzeszowie (dalej: APRz), Akta miasta Rzeszowa (dalej: AmRz), sygn., k. 358 .

${ }^{4}$ APRz, AmRz, sygn. 3444, k. 2.

${ }^{5}$ B. Tondos, Architektura Rzeszowa w okresie autonomii galicyjskiej, Rzeszów 1997, s. 19-20.

${ }^{6}$ B. Tondos, Apperman Izaak, [w:] Encyklopedia Rzeszowa, red. Z. Budzyński, J. Draus, J. Kawałek, J. Malczewski, Z. Nawrocki, Z. Wójcik, G. Zamoyski, Rzeszów 2004, s. 14; taż, Apperman Izaak, [w:] Encyklopedia Rzeszowa, red. J. Draus i G. Zamoyski, Rzeszów 2011, s. 20.

${ }^{7}$ A. Myszka, P. Wisz, Nazwy ulic Rzeszowa. Historia i wspótczesność, Rzeszów 2012, s. 253.

${ }^{8}$ APRz, AmRz, sygn. 1988.
} 
Projekt budynku przewidywał, że jego głównym przeznaczeniem będzie funkcja budynku czynszowego. Świadczyć o tym może rozmieszczenie 17 mieszkań na trzech kondygnacjach Na parterze projektowanego budynku mieściło się pięć mieszkań (dwu lub jednopokojowych z kuchniami i w dwóch przypadkach ze spiżarniami) oraz dwa pomieszczenia handlowe $\mathrm{z}$ wejściem od strony ul. Kopernika. Układ obu pięter był identyczny - na obu piętrach były mieszkania trzypokojowe $\mathrm{z}$ kuchnią, dwa mieszkania dwupokojowe $\mathrm{z}$ kuchnią, mieszkanie dwupokojowe z kuchnią i spiżarnią, mieszkanie jednopokojowe z kuchnią i spiżarnią oraz mieszkanie jednopokojowe z kuchnią. Powierzchnia najmniejszych mieszkań wynosiła 40,4 $\mathrm{m}^{2}$, zaś największe mieszkania trzypokojowe miały powierzchnię $76 \mathrm{~m}^{2}$. Jak wskazują dane spisu ludności Rzeszowa pod koniec 1910 roku budynek ten zamieszkiwało 107 osób ${ }^{9}$.

Budynek ten miał dwa wejścia i dwie niezależne klatki schodowe. Jedna od strony dzisiejszej ulicy Okrzei prowadziła sienią w stronę klatki schodowej. Druga - przez przejazd od strony obecnej ulicy Kopernika na podwórze i stąd klatką schodową na kolejne kondygnacje.

Innym budynkiem przeznaczonym na cele mieszkalne i zaprojektowanym przez tego architekta był budynek przy ulicy Zamkowej 5. Apperman jako wykonał projekt prawdopodobnie w 1896 roku $^{10}$. Niestety - również ten projekt budynku zachował się fragmentarycznie - brak bowiem rzutów kolejnych kondygnacji a zachował się tylko rysunek fasady oraz przekrój boczny. Ten dwupiętrowy budynek $\mathrm{z}$ wejściem usytuowanym $\mathrm{z}$ boku jest typowym budynkiem mieszkalnym. Inwestorzy - byli nimi Alojzy i Maria Niemietz, zdecydowali się zbudować budynek dwupiętrowy, zapewne w celu zwiększenia liczby mieszkań i powiększenia dochodów uzyskiwanych z czynszu ${ }^{11}$.

Wśród budynków mieszkalnych, projektowanych przez Izaaka Appermana w Rzeszowie zachowały się także projekty domów przy ulicy Nowe Miasto (obecnie Plac Wolności) oraz dwa budynki w rejonie ulicy Trzeciego Maja. Pierwszy z nich to budynek Sperlingów na rogu ulic Trzeciego Maja i Dymnickiego a drugi to niewielki budynek małżeństwa Spitzów na ulicy Dymnickiego. [5 6]

Projekt budynku przy ulicy Nowe Miasto miał być realizowany na zamówienie Eliasza Grünsteina, który w styczniu 1891 r. wystąpił z prośbą o zezwolenie na budowę i przedstawił plany nowego budynku, w którym miało się pomieścić także nowe pomieszczenia dla zakładu blacharsko-rzemieślniczego ${ }^{12}$. Projekt budynku autorstwa I. Appermana ograniczały rozmiary działki $(10,40 x 61,30 \mathrm{~m})$, na której miał powstać budynek. Fasada frontowa dwupiętrowego budynku widoczna była od strony rynku nowomiejskiego a cały budynek przechodzący

\footnotetext{
${ }^{9}$ APRz, AmRz, sygn. 1530, passim.

${ }^{10}$ APRz, AmRz, sygn. 2000.

${ }^{11}$ Wykaz domów w mieście Rzeszowie z nowemi nazwami ulic i placów, oraz z liczbami oryentacyjnemi, liczbami spisowemi i liczbami wykazów hipotecznych, Rzeszów 1899, s. 17.

${ }^{12}$ APRz, AmRz, sygn. 3427, s. 265.
} 
w kształt oficyny składał się z coraz niższych segmentów, ciągnących się do Mikośki płynącej poza granicą działki i ówczesnej ulicy Zielonej ${ }^{13}$. Na parterze i kolejnych kondygnacjach projektant umiejscowił trzypokojowe mieszkania z kuchnią oraz klatkę schodową po prawej stronie wejścia. Mieszkania znajdowały się także w parterze oficyny oraz na pierwszym jej piętrze a wejście do nich było możliwe dzięki wejściu na balkon od strony klatki schodowej. Parter oficyny zajmowały pomieszczenia warsztatu ślusarskiego. W sąsiedztwie umieszczony został pion sanitarny a nieczystości odprowadzano kanałem do Mikośki. Pierwotny projekt I. Appermana został jednak po uwagach miejskiej komisji budowlanej przerobiony i w lipcu $1891 \mathrm{r}$. ostatecznie zaakceptowany. W stosunku do planu wcześniejszego zaprojektowano dodatkową półkolistą klatkę schodową, która umożliwiała wejście do mieszkań w oficynie. W maju 1892 roku inwestor zwrócił się on do władz miasta prośbą o zgodę na zamieszkanie w nowo wybudowanym domu $^{14}$ (rys. 1.).

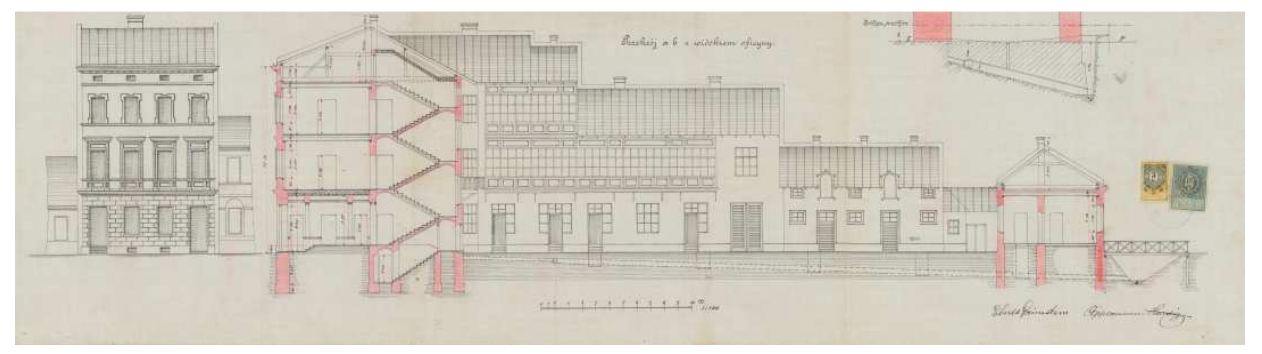

Rys. 1. Projekt domu Grünsteina przy ul. Nowe Miasto (AmRz, sygn. 3427, s. 273)

Fig. 1. Project of the Grünstein's House at New City Street (AmRz, sygn. 3427, s. 273)

W roku 1893 Apperman zaprojektował budynek mieszkalny dla Eisiga i Jochwety Spitzów, który miał stanąć przy ówczesnej ulicy Różanej (obecnie Dymnickiego). To typowy budynek przeznaczony dla wynajmu mieszkań. Według projektu miał on być przeznaczony dla czterech rodzin, zamieszkujących ten dwukondygnacyjny budynek. Starania o budowę domu, podjęte przez małżeństwo Spitzów jeszcze w 1891 r., wiązały się z koniecznością wyburzenia części dotychczasowych murów, jako zagrażających bezpieczeństwu i grożących zawaleniem. Mimo uzyskania pozwolenia na budowę, budynek ostatecznie nie powstał ${ }^{15}$.

W bezpośrednim sąsiedztwie działki Spitzów Apperman zaprojektował i wybudował reprezentacyjny budynek dla Wilhelma i Róży Sperlingów na rogu ulic Trzeciego Maja i Dymnickiego. Projekt pochodzący z 1904 roku zakładał zbudowanie dwupiętrowej kamienicy z przylegającym do niego parterowym budynkiem

\footnotetext{
${ }^{13}$ APRz, AmRz, sygn. 3427, s. 275.

${ }^{14}$ APRz, AmRz, sygn. 3427, s. 258.

${ }^{15}$ APRz, AmRz, sygn. 3444, k. 137 i nast.
} 
magazynowym przy ulicy Dymnickiego. Na parterze miały znajdować się pomieszczenia dla czterech sklepów, posiadających własne pomieszczenia magazynowe. Od strony ulicy miało także znajdować się główne wejście do budynku a na piętrach po dwa duże, czteropokojowe mieszkania wraz z kuchnią, spiżarnią i łazienkami. Jednak ubikacje nadal mieściły się na balkonach na zewnątrz budynku ${ }^{16}$. Kolejne komisje, odwiedzające plac budowy stwierdziły dokonanie nieznacznych zmian w projekcie, ale w 1904 r. zmusiły inwestora do zaprzestania rozbierania kanału ściekowego, biegnącego przez teren Sperlinga i odprowadzającego ścieki z budynków gimnazjum i starostwa (rys. 2.).

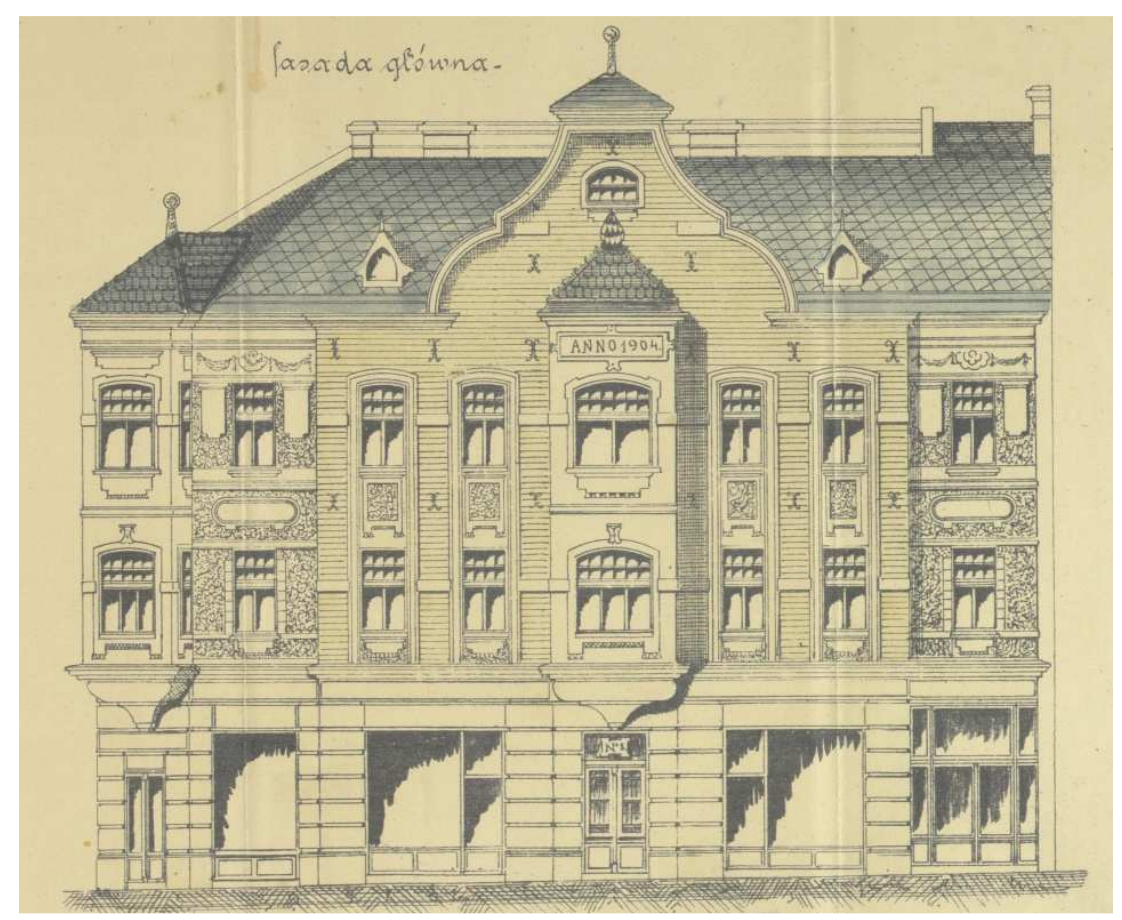

Rys. 2. Projekt domu Sperlingów przy ul. Trzeciego Maja w Rzeszowie (AmRz, sygn. 3444, s. 1)

Fig. 2. Project of Sperling's House at Third May Street in Rzeszów (AmRz, sygn. 3444, s. 1)

Dopiero po przeprowadzeniu koniecznych poprawek gmach został dopuszczony do zamieszkania w 1906 r. ${ }^{17}$

\footnotetext{
${ }^{16}$ APRz, AmRz, sygn. 3444, k. 1-3.

${ }^{17}$ APRz, AmRz, sygn. 3444, k. 4 i nast.
} 
Jak się wydaje - Izaak Apperman pojawił się w Rzeszowie w 1890 roku w związku z budową nowego gmachu tutejszej Kasy Oszczędności. Nie udało się bowiem odnaleźć dokumentów, wskazujących na wcześniejszą działalność tego architekta na terenie Rzeszowa. Budynek tej Kasy był budowany na parceli, bezpośrednio przylegającej do gmachu rzeszowskiego gimnazjum (to dzisiejszy budynek Galerii Paniaga). Nie zachowały się plany tego budynku i nie wiadomo kto był jego projektantem. I. Apperman wystąpił więc w tym przypadku jako budowniczy, podpierając się sporządzonymi w Wiedniu finansowymi gwarancjami ukończenia budowy w terminie, o czym wspomniano wcześniej (rys. 3.).

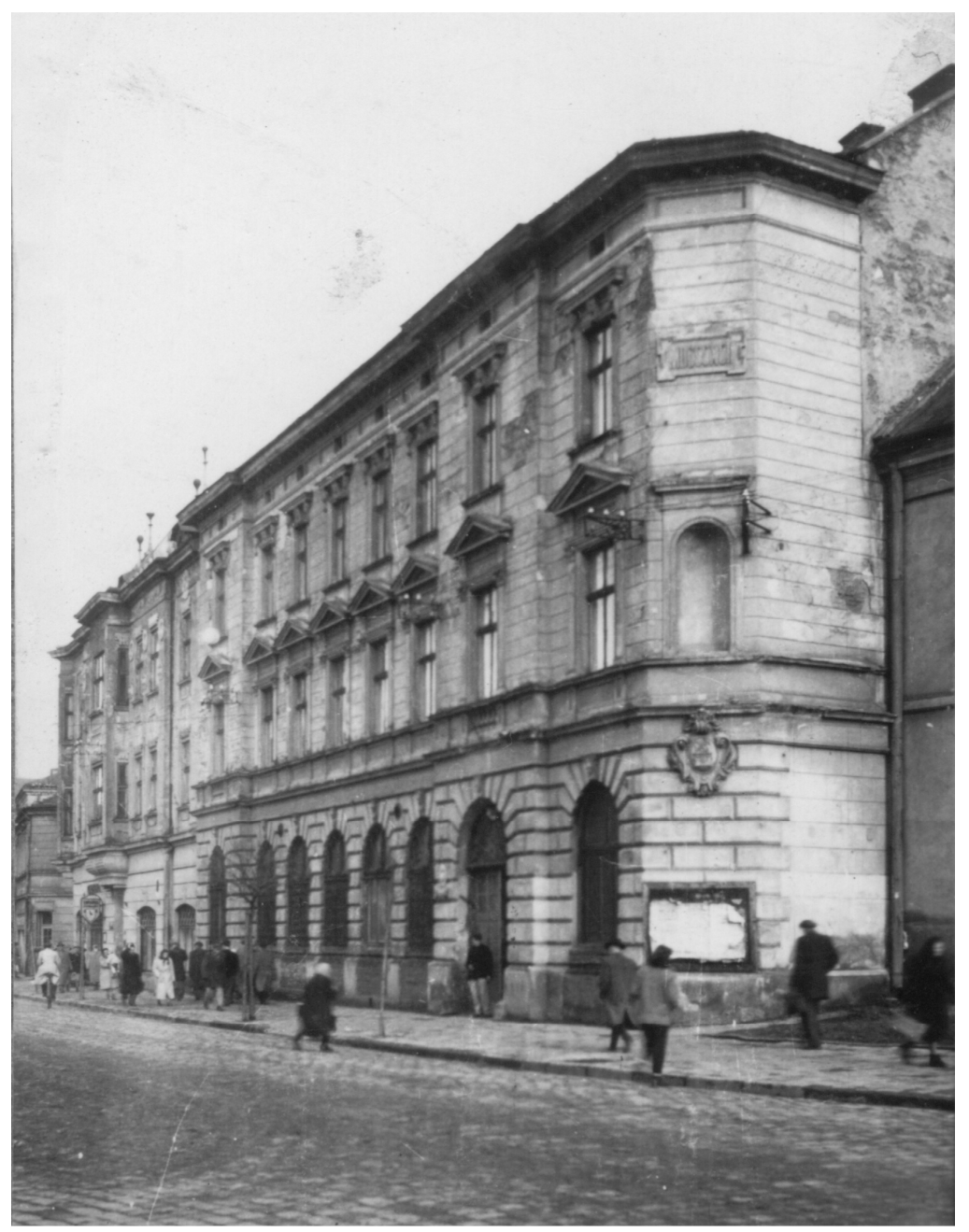

Rys. 3. Budynek rzeszowskiej Kasy Oszczędności w latach 50-tych XX wieku

Fig. 3. The building of the Rzeszów Savings Bank in the 50's of the 20th century 
W czerwcu 1890 r. architekt złożył ofertę wybudowania gmachu za ryczałtową kwotę 45 tys. zł, która przez dyrekcję Kasy została przyjęta ${ }^{18}$. Było to zapewne spowodowane faktem, że wcześniejsze przetargi zakończyły się niepowodzeniem, bowiem nikt nie zgłosił się do wybudowania budynku za - jak się wydaje niewielkie środki ${ }^{19}$.

Po objęciu robót rzez Appermana w listopadzie następnego roku budynek został oddany do użytku. Po kilkunastu latach Kasa Oszczędności przeniosła się jednak do nowej siedziby, zaprojektowanej przez Jana Perosia na końcu ulicy Trzeciego Maja a dotychczasowy budynek był wykorzystywany przez rzeszowski oddział Towarzystwa Szkoły Ludowej (TSL).

Izaak Apperman współpracował także z rzeszowską gminą wyznaniową, reprezentując ją jako specjalista $\mathrm{w}$ zakresie budownictwa, $\mathrm{w}$ działaniach na rzecz odbudowy i konserwacji majątku gminy. Przeprowadził m.in. rekonstrukcję budynku gminnego przy ówczesnej ulicy Owocowej (dzisiejszej Mickiewicza), w którym znajdowały się pomieszczenia władz miejscowego kahału.

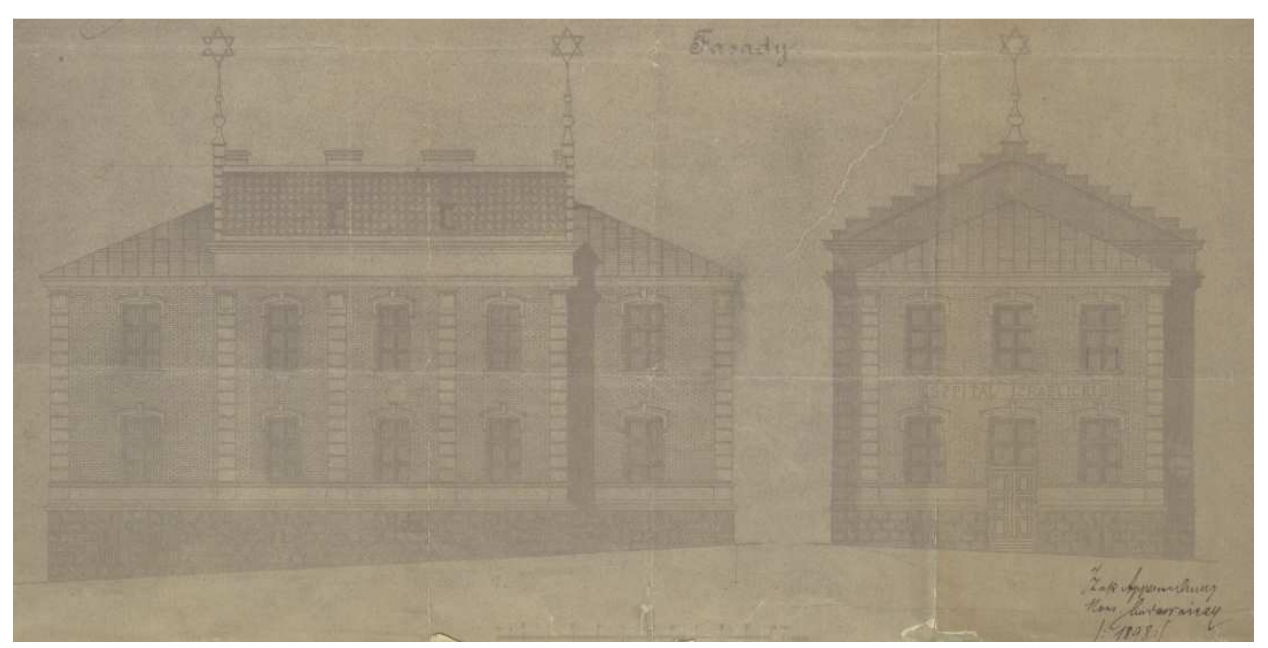

Rys. 4. Projekt szpitala gminy izraelickiej w Rzeszowie (AmRz, sygn. 3390, s. 387)

Fig. 4. Project of the hospital of the Jewish community in Rzeszów (AmRz, sygn. 3390, s. 387)

Przykładem współpracy może być projekt budowy szpitala izraelickiego dla 36 chorych, który miał powstać przy ulicy Baldachówka (rys. 4.). Władze gminy izraelickiej uznały konieczność budowy nowego szpitala, bowiem dotychczas funkcjonujący przy ul. Wąskiej nie odpowiadał wymaganiom higienicznym a opi-

${ }^{18}$ APRz, AmRz, sygn. 3364, s. 315.

${ }^{19}$ APRz, AmRz, sygn. 3364, s. 320. 
nia ko-misji powołanej przez władze miasta, w której pracach uczestniczył również I. Apperman, potwierdzała konieczność likwidacji dotychczasowej placówki ${ }^{20}$.

Pochodzący z lat 1898-1899 projekt budowy szpitala zakładał wybudowanie jednopiętrowego obiektu dla 36 chorych - na parterze oddział dla mężczyzn a na piętrze dla kobiet. Na parterze obok sal chorych przewidywano m.in. pomieszczenia dla sali operacyjnej i ambulatorium ${ }^{21}$. Mimo uzyskania w lipcu 1899 r. konsensu (pozwolenia) na budowę, wobec ostrych protestów sąsiadów m.in. rodziny Silberów, sprawa budowy tego szpitala upadła, bowiem wykazano, że rzeszowski Magistrat wydając zgodę popełnił poważne błędy proceduralne. Krajowe władze uznały za zasadny także argument, że funkcjonował już w Rzeszowie szpital powszechny i korzystali z niego Żydzi i pracują tam żydowscy lekarze.

Współpracując z rzeszowską gminą wyznaniową - w 1904 r. Apperman przygotował plany przeprowadzenia remontu budynku gminnego przy ulicy Bożniczej (późniejszy budynek Archiwum Państwowego) a także wybudowania budynków i urządzeń sanitarnych w domu ubogich na rogu ulic Sobieskiego i Wąskiej $^{22}$. Było to ostatnie zamówienie od tej instytucji, stanowiące swoiste zakończenie współpracy, rozpoczętej jeszcze w 1896 r. wykonaniem ekspertyzy w synagodze Klaus (obecna synagoga staromiejska) i wskazaniem na konieczność przerobienia prowadzących do niej schodów ${ }^{23}$.

Wyjątkowe miejsce w działalności projektowej Appermana w Rzeszowie zajmuje projekt budynku fabrycznego, za jaki można uznać projekt rzeźni, powstałej na terenie Ruskiej Wsi, stanowiącej wówczas odrębną gminę. Jeszcze w 1890 r. rzeszowskie Starostwo nakazało władzom tej gminy budowę nowego obiektu, gdyż dotychczasowy nie odpowiadał obowiązującym wymogom sanitarnym $^{24}$. Jej budowa wywoływała wiele zastrzeżeń, do których w 1895 r. zaliczano niewielką odległość od budynków mieszkalnych, brak dostępnych źródeł wody oraz potencjalne trudności z usuwaniem odpadów poprodukcyjnych. Wskazywano nawet na niekorzystny układ wiatrów, które mogły przenosić przykry zapach na tereny miasta - szczególnie na pobliska ulicę Krakowską i znajdujący się tam gmach seminarium nauczycielskiego ${ }^{25}$.

W lipcu 1898 r. na terenie Ruskiej Wsi przy torze kolei Rzeszów-Jasło uruchomiono rzeźnię, której projektantem był I. Apperman. Mimo licznych uwag, że jej powstanie mogłoby zaszkodzić mieszkańcom pobliskiej ulicy Krakowskiej, rzeźnia została uruchomiona. I. Apperman zaprojektował ją w 1896 roku i jego

\footnotetext{
${ }^{20}$ APRz, AmRz, sygn. 3425, s. 365.

${ }^{21}$ APRz, AmRz, sygn. 3390, k. 387-388.

${ }^{22}$ APRz, AmRz, sygn. 3425, passim.

${ }^{23}$ APRz, AmRz, sygn. 3425, s. 383.

${ }^{24}$ APRz, AmRz, sygn. 3427, k. 117.

${ }^{25}$ APRz, AmRz, sygn. 3427, k. 114-115.
} 
projekt został przyjęty, choć projekty takie złożyli m.in. Ludwik Holzer i J. Chylewski, właściciel fabryki maszyn i „odlewarni” w Tarnowie ${ }^{26}$. Projekt Appermana został ,użyty przy komisji” we wrześniu 1896 r. i zatwierdzony do budowy decyzją władz gminy.

Zachowany projekt Appermana nie jest kompletny - gdyż brak w zachowanej dokumentacji rzutów projektowanego budynku. Obiekt miał znajdować się na granicy Ruskiej Wsi i Rzeszowa i - oprócz budynku głównego - składać się ze studni, zbiornika na nieczystości i kloak. Długość budynku głównego miała wynosić $32 \mathrm{~m}$ a szerokość $9,80 \mathrm{~m}$, zaś wysokość pomieszczeń $4,20 \mathrm{~m}$. W budynku miały znajdować się płuczkarnie jelit dla bydła i trzody, rzeźnie dla bydła, trzody i cieląt oraz pomieszczenia dla pracowników - w tym weterynarza. W budynku mieściła się także kotłownia. Warto także zwrócić uwagę na odrębne pomieszczenie przeznaczone dla rzezaka rytualnego ${ }^{27}$ (rys. 5.).

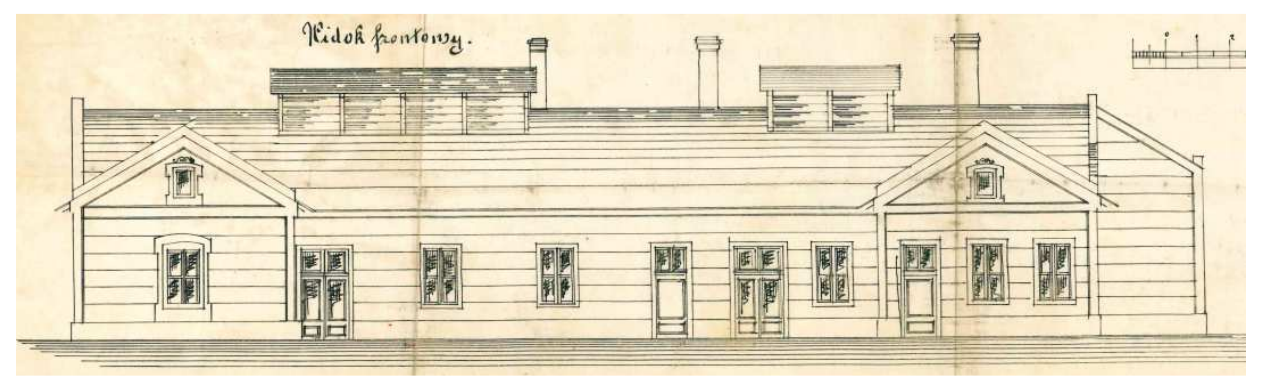

Rys. 5. Projekt budynku rzeźni w Ruskiej Wsi (AmRz, sygn. 2004, s. 28)

Fig. 5. Project of the slaughterhouse building in Ruska Wieś (AmRz, sygn. 2004, s. 28)

Woda miała być do pomieszczeń płuczkarni doprowadzona rurami ze studni do basenów, z których odprowadzona miała być ściekami do podziemnych zbiorników. Wszystkie pomieszczenia uboju miały być wyposażone na posadzce betonowej w tzw. rynzole do odprowadzania wody. Oprócz tego w pomieszczeniach tych projektant umieścił przyrządy mechaniczne do łatwego pionowego wyciągania i przesuwania tusz, co miało także ułatwić ich oprawianie. Zgodnie z wymaganiami Starostwa zaprojektowany został nad pomieszczeniami produkcyjnymi dach otwarty przy użyciu tzw. rajterów (nie było więc strychów) - co miało poprawić wentylację w budynku ${ }^{28}$.

Po włączeniu Ruskiej Wsi do Rzeszowa w 1902 r. budynek ten wyceniony został na 36 tys. koron i wraz z gruntem wpisany do majątku miasta. Wkrótce

\footnotetext{
${ }^{26}$ APRz, AmRz, sygn. 3427, s. 109.

${ }^{27}$ APRz, AmRz, sygn. 3427, k. 109.

${ }^{28}$ APRz, AmRz, sygn. 3427, k. 104-105.
} 
jednak został rozebrany, gdyż miasto zbudowało nową rzeźnię w bezpośrednim sąsiedztwie starego cmentarza i elektrowni miejskiej.

Izaak Apperman był również wykonawcą projektów innych architektów. Tak było w przypadku budowy koszar dla policji miejskiej, znajdujących się obecnie przy ulicy Lisa-Kuli (rys. 6.). Z dużym prawdopodobieństwem można przyjąć, że jest to projekt W. Buczaniewicza ${ }^{29}$. Projekt pochodzi z $1891 \mathrm{r}$. i jest przykładem pięknego rysunku architektonicznego. Wiosną 1892 r. Apperman w imieniu swoim oraz Adolfa Sandiga i Herscha Grünsteina jako wspólników zwrócił się do władz miasta o wypłatę reszty należności za wykonanie budowy. Jednak przez cały rok 1893 władze miejskie Rzeszowa zwlekały z wypłatą i wyszukiwały kolejne drobne odstępstwa od projektu, zwlekając z wypłatą należności. Dopiero groźba skierowania sprawy na drogę sądową i obowiązek pokrycia odsetek za zwłokę spowodowały, że w maju 1894 r. - a więc dopiero po dwóch latach od odebrania budynku - doszło do podpisania ugody i wypłacenia zaległej sumy ${ }^{30}$.

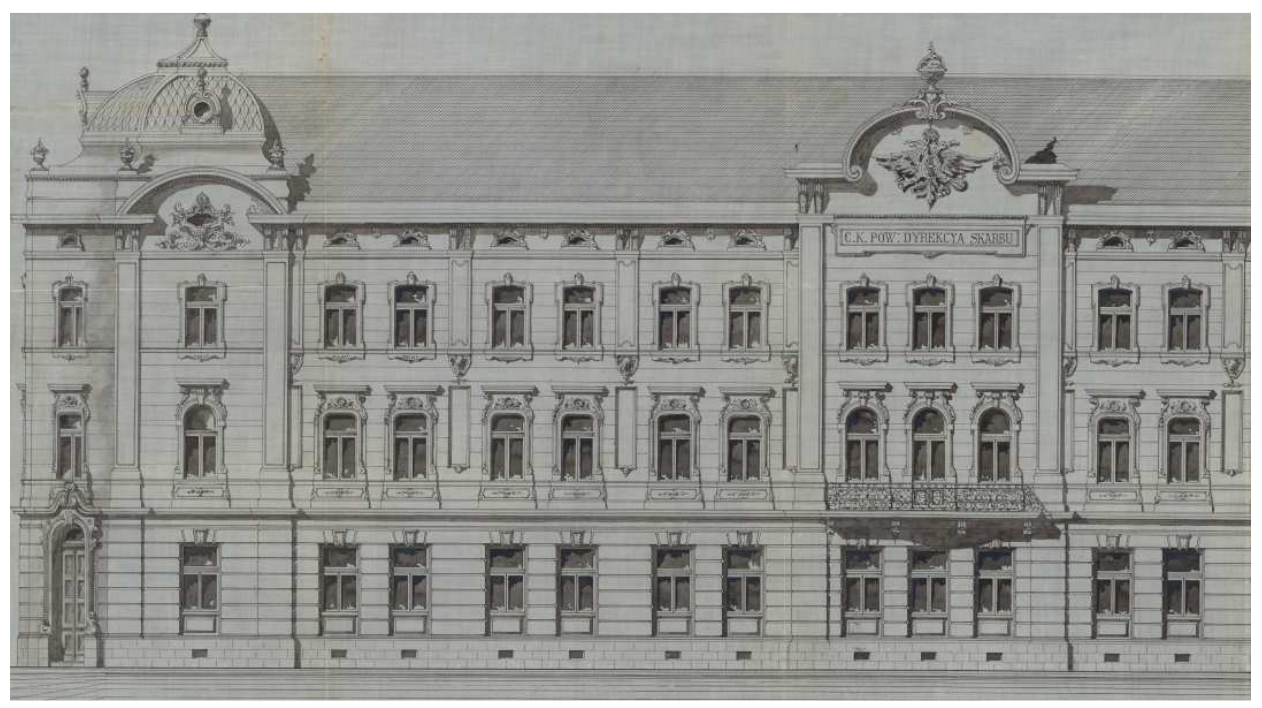

Rys. 6. Projekt budynku Izby Skarbowej w Rzeszowie przy ul. Zamkowej (AmRz, sygn. 3447, s. 155)

Fig. 6. Procjet of the Tax Chamber Building in Rzeszów at Castle Hill Street (AmRz, sygn. 3447, s. 155)

\footnotetext{
${ }^{29}$ Świadczy o tym przede wszystkim kolorystyka i rysunek projektu, który został pominięty przez B. Tondos wśród prac tego architekta; B. Tondos, op. cit., s. 60. Autorka tej monografii myli się podając, że ówczesna ulica Sandomierska to ulica ks. Jałowego - w rzeczywistości chodzi o dzisiejszą ulicę Grunwaldzką.

${ }^{30}$ APRz, AmRz, sygn. 3422, k. 219.
} 
Budynek CK powiatowej Dyrekcji Skarbu w Rzeszowie zaprojektował Apperman, lecz budował go wraz z Adolfem Sandigiem, z którym wcześniej współpracował przy budowie koszar policji. Budynek został zbudowany na parceli, która należała wcześniej do obu przedsiębiorców i obok kamienicy, przez nich wcześniej zbudowanej ${ }^{31}$. Projekt gmachu, złożony w sierpniu 1894 r. skrytykował ówczesny budowniczy miejski Kazimierz Hołubowicz, stwierdzając m.in. że ,fasada nie odpowiada zasadom dobrego smaku"32. Władze miejskie starały się utrudnić rozpoczęcie budowy, wskazując na problemy zabezpieczenia ogniowego i starając się zmusić inwestorów do sporządzenia odprowadzenia ścieków na ich koszt ze znacznego obszaru ulic Trzeciego Maja i Zamkowej. Zachowana korespondencja wskazuje na nadmierną ingerencję władz rzeszowskich i ich miejskiego budowniczego, mimo faktu, że plany zostały zatwierdzone przez Ministerstwo Skarbu ${ }^{33}$. W czerwcu 1896 r. budowę ukończono, lecz dopiero w lutym $1897 \mathrm{r}$. komisja miejska wydała zgodę na użytkowanie budynku ${ }^{34}$.

Innym przykładem projektowania na potrzeby miejscowej gminy jest projekt budynku szpitala zakaźnego przy szpitalu powszechnym w Rzeszowie, który Apperman przedłożył do zatwierdzenia w $1895 \mathrm{r} .{ }^{35}$ Budynek stanowił niezbędne uzupełnienie powstałego kilka lat wcześniej kompleksu szpitala powszechnego przy ulicy Naruszewicza a wybudowali go miejscowi przedsiębiorcy Bernard Hirschhorn i Izrael Dunkelblau w 1896 r. Projekt Appermana przewidywał na każdej kondygnacji po 2 sale dla chorych, pokój dla lekarza oraz pomieszczenia sanitarne. Podłogi miały być betonowe w celu łatwiejszego utrzymania czystości, co było możliwe dzięki zastosowaniu trawersów ${ }^{36}$. Podobnie, jak w innych przypadkach władze miasta zwlekały z wypłatą należności za sporządzenie projektu.

Izaak Apperman prawdopodobnie równolegle z pracą w Rzeszowie wykonywał zlecenia także w innych miastach a brak jego zameldowania w Rzeszowie zdaje się to poświadczać. Był przykładem ówczesnego architekta i przedsiębiorcy budowlanego. Trudna do zweryfikowania pozostaje kwestia uczestnictwa Appermana w budowie tak charakterystycznego gmachu, jakim jest budynek rzeszowskiego „Sokoła”. Był praktycznie jedynym tak aktywnym architektem żydowskim działającym w tym czasie w Rzeszowie.

\section{Literatura}

[1] B. Tondos, Architektura Rzeszowa w okresie autonomii galicyjskiej, Rzeszów 1997;

[2] Encyklopedia Rzeszowa, red. Z. Budzyński, J. Draus, J. Kawałek, J. Malczewski, Z. Nawrocki, Z. Wójcik, G. Zamoyski, Rzeszów 2004;

\footnotetext{
${ }^{31}$ Projekt tego budynku Józefa i Amalii Schönblum nie zachował się.

${ }^{32}$ AmRz, sygn. 3447, s. 181.

${ }^{33}$ AmRz, sygn. 3447, s. 204-215.

${ }^{34}$ AmRz, sygn. 3447, s. 132-133.

35 AmRz, sygn. 3422, s. 365.

${ }^{36}$ AmRz, sygn. 3422, s. 217.
} 
[3] Encyklopedia Rzeszowa, red. J. Draus i G. Zamoyski, Rzeszów 2011;

[4] A. Beider, A dictionary of jewish surnames from Galicia, Bergenfield 2004;

[5] A. Myszka, P. Wisz, Nazwy ulic Rzeszowa. Historia i wspótczesność, Rzeszów 2012;

[6] Wykaz domów w mieście Rzeszowie z nowemi nazwami ulic i placów, oraz z liczbami oryentacyjnemi, liczbami spisowemi i liczbami wykazów hipotecznych, Rzeszów 1899.

\section{IZAAK APPERMAN - A FORGOTTEN ARCHITECT FROM RZESZÓW}

\section{S u m m a r y}

Isaac Apperman was the most active Jewish architect, operating in Rzeszów at the end of the 19th century. His biography hides many secrets - no documents related to his living in this city could be found. He worked in Vienna, but many of his works were completed in Rzeszów. He was a designer of some edifices; but also - while running his own construction company -a performer of other architects' designs. He left some edifices that permanently entered the city landscape. Those buildings were built for the needs of the city, the local Jewish community, state institutions, associations and individuals. They include the preserved buildings of the Rzeszów "Sokól" Gymnastic Association (Bernardyńska Street), of the isolation hospital (Naruszewicza Street), of the Treasury Chamber (Zamkowa Street), of the Savings Bank (of the current Gallery "Paniaga" at Trzeciego Maja Street), of the city guards (now Lisa-Kuli Street), the private buildings on the streets of Trzeciego Maja, Dymnickiego or Kopernika, and finally the design of slaughterhouses in Ruska Wieś. For his research the Authorused the archives of the State Archive in Rzeszów, preserved in a good condition and gathered inthe collection called The Files of the City of Rzeszów. This documentation includes the designs of buildings and the correspondence with investors and city authorities, giving permissions for building of the edifices, and with supervisors of the investmentimplementations.

Keywords: history of architecture, Galicia, Rzeszów, architects in Rzeszów

Przestano do redakcji: 09.06.2017 $r$.

Przyjęto do druku: 01.09.2017 r. 